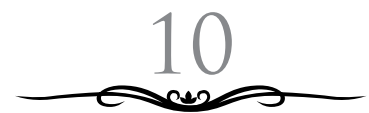

\title{
PEMANFATAN MEDIA SOSIAL PADA PERPUSTAKAN KOTA LITERASI \\ (Studi Kasus Perpustakaan Daerah Kabupaten Sragen)
}

\author{
Jiyanto dan Muhammad Miftah \\ IAIN Surakarta, STAIN Kudus Jawa Tengah, Indonesia \\ Jiyanto89@yahoo.com
}

\begin{abstract}
In its function as an information center, the library preoccupied with activities of collecting, evaluating, selecting, and disseminate information needed by users. In carrying out its functions to review its serve the needs of the library are encouraged to review seeing as the technology advancement partners help functions the library. The declaration of the city as Sragen regency make library literacy program activity center hearts as that government. In support of the government's program, the public library in Sragen requires different means of supporting the hearts promoting literacy self as its center. One means of supporting the effective was with using social media. This article examines the utilization of social media regarding at sragen local library. Purpose of study singer for the review to know how social media utilization in cities literacy.
\end{abstract}

Keywords: Utilization, Social Media, Local Library, Cities Literacy

\begin{abstract}
Abstrak
Dalam fungsinya sebagai pusat informasi, perpustakaan sangat disibukkan dengan kegiatan mengumpulkan, mengevaluasi, menyeleksi, dan menyebarkan informasi yang dibutuhkan oleh penggunanya. Di dalam menjalankan fungsinya untuk melayani
\end{abstract}


kebutuhan penggunanya tersebut, perpustakaan dipacu untuk melihat kemajuan teknologi sebagai partner yang membantu fungsi perpustakaan itu sendiri. Pencanangan kota Sragen sebagai Kabupaten Literasi menjadikan perpustakaan sebagai pusat kegiatan dalam program pemerintah tersebut. Dalam mendukung program pemerintah tersebut, Perpustakaan Umum Daerah Sragen membutuhkan berbagai sarana penunjang dalam mempromosikan diri sebagai pusatnya literasi. Salah satu sarana penunjang yang efektif adalah dengan menggunakan sosial media. Tulisan ini mengkaji mengenai pemanfaatan sosial media pada perpustakaan daerah Kabupaten Sragen. Tujuan dari kajian ini untuk mengetahui bagaimana pemanfaatan sosial media di kota literasi.

Kata Kunci: Pemanfaatan, Media Sosial, Perpustakaan Daerah, Kota Literasi

\section{A. Pendahuluan}

Perpustakaan merupakaan jendela dunia, masyarakat bisa mengetahui dan memahami perkembangan jaman melalui membaca. Dengan gemar membaca akan menambah pengetahuan seseorang, mereka yang sebelumnya tidak tahu akan menjadi tahu. Buku merupakan pembuka pandangan kita, dari hanya sebuah buku kita dapat mengetahui isi dunia serta pengetahuan yang tak ternilai harganya.

Perpustakaan memberikan banyak manfaat bagi para pembacanya, tetapi masih sedikit sekali masyarakat yang sadar akan manfaat yang diberikan. Kondisi minat baca bangsa Indonesia memang memprihatinkan. Berdasarkan studi "Most Littered Nation In The World" yang dilakukan oleh Central Connecticut State University pada Maret 2016 Indonesia dinyatakan menduduki peringkat ke-60 dari 61 negara soal minat membaca. Indonesia persis berada di bawah Thailand (59) dan di atas Bostwana (61). Padahal dari segi penilaian infrastruktur peringkat Indonesia berada di atas Negara-negara Eropa. ${ }^{1}$

1 Kompas, Minat Baca Indonesia ada di urutan ke-60 Dunia, 2016, http:// www.edukasi.kompas.com/read/2016/08/29/07175131/minat.baca.indonesia.ada. di.urutan.ke-60.dunia, Diakses pada 31 Desember 2016 pada pukul 08.00 WIB 
Dari fenomena di atas berbagai upaya dari pemerintah daerah dalam meningkatkan kesadaran masyarakat akan budaya membaca terus diupayakan. Salah satunya adalah dengan mencanangkan program pemerintah daerah dengan menjadikan daerahnya sebagai kota literasi. Hal tersebut seperti dilakukan oleh Kabupaten Sragen di tahun 2016. Tepatnya pada 27 Mei 2016 Bupati Sragen terpilih Kusnindar Untung Yuni Sukowati mencanangkan Sragen sebagai Kabupaten Literasi. Pencanangan Kabupaten Literasi tersebut dianggap sebagai bagian investasi mencerdaskan bangsa.

Pencanangan Sragen sebagai Kabupaten Literasi itu didukung USAID Prioritas. USAID Prioritas menjadi mitra sekitar 17 sekolah di Sragen. Lembaga itu juga membagikan buku bacaan kepada 125 SD dalam rangka menumbuhkan minat baca siswa. "Dipilihnya Sragen untuk dicanangkan sebagai Kabupaten Literasi ini karena hampir 50\% sekolah menerapkan berbagai program dalam rangka meningkatkan minat baca. Sejumlah sekolah sudah mewajibkan siswa untuk membaca buku selain mata pelajaran selama beberapa menit. Biasanya di setiap kelas ada pojok baca yang menyimpan berbagai buku bacaan," terang Suwardi. ${ }^{2}$

Dalam mendukung program pemerintah tersebut, Perpustakaan Umum Daerah Sragen membutuhkan berbagai sarana penunjang dalam mempromosikan diri sebagai pusatnya literasi. Salah satu sarana penunjang yang efektif adalah dengan menggunakan sosial media. Media sosial merupakan teknologi yang sangat popular dan digunakan hampir semua penduduk di muka bumi ini bagi tujuan berinteraksi atau berhubung di antara satu sama lain.

Perkembangan teknologi komputer, telekomunikasi, informasi memberikan dampak yang sangat besar bagi perpustakaan. Perkembangan ini memunculkan berbagai penamaan baru dalam konsep perpustakaan modern seperti perpustakaan tanpa dinding (Library without walls), perpustakaan dijital (digital library),

${ }^{2}$ USAID Prioritas, Sragen Deklarasikan Jadi Kabupaten Literasi, 2016, http://www.prioritaspendidikan.org/id/post/920/sragen/-deklarasikan-jadikabupaten-literasi, diakses pada 31 Desember 2016 pada pukul 08.00 
perpustakaan maya (virtual library), maupun perpustakaan elektronik (e-library).

Dalam fungsinya sebagai pusat informasi, perpustakaan sangat disibukkan dengan kegiatan mengumpulkan, mengevaluasi, menyeleksi, dan menyebarkan informasi yang dibutuhkan oleh penggunanya. Di dalam menjalankan fungsinya untuk melayani kebutuhan penggunanya tersebut, perpustakaan dipacu untuk melihat kemajuan teknologi sebagai partner yang membantu fungsi perpustakaan itu sendiri. Penggunaan teknologi komputer yang terus berkembang, dimanfaatkan untuk sarana penyimpanan dan temu kembali informasi yang efisien dan efektif. Dengan berkembangnya teknologi Internet, keberadaan website menjanjikan sebagai sarana yang efektif untuk memasarkan produk-produk layanan perpustakaan untuk mencapai target pengguna yang diinginkan.

Media sosial sangat diperlukan dalam kemajuan sebuah perpustakaan, saat ini perpustakaan menciptakan membuat satu akun untukhubungan antara pengguna dan juga komuniti masyarakat. Dengan media sosial perpustakaan dapat memberikan informasi-informasi yang bisa "memprovokasi" publik dalam banyak hal, misalnya dengan sering menyerukan terkait pentingnya budaya membaca, pentingnya perpustakaan, pengawasan dalam kebijakan pemerintah yang mungkin dinilai kurang dalam memajukan dunia perpustakaan, dan masih banyak lagi yang bisa dilakukan oleh media sosial dalam membantu memajukan dunia perpustakaan di indonesia.

Tulisan ini mengkaji mengenai pemanfaatan sosial media pada perpustakaan daerah Kabupaten Sragen. Tujuan dari kajian ini untuk mengetahui bagaimana pemanfaatan sosial media di kota literasi dalam upayanya menumbuhkan kesadaran minat baca masyarakat Kabupaten Sragen. 


\section{B. Pembahasan}

\section{Konsep Pemanfaatan Media Sosial Pada Perpustakaan}

\section{a. Pengertian Media Sosial}

Menurut Hanson dalam Hadi Purnama, social media atau dalam bahasa Indonesia disebut media sosial adalah media yang didesain untuk memudahkan interaksi sosial yang bersifat interaktif atau dua arah. Media sosial berbasis pada teknologi internet yang mengubah pola penyebaran informasi dari yang sebelumnya bersifat satu ke banyak audiens, banyak audiens ke banyak audiens. ${ }^{3}$

Menurut Andreas Kaplan dan Michael Haenlein mendefinisikan media sosial sebagai sebuah kelompok aplikasi berbasis internet yang dibangun di atas dasar ideologi dan teknologi web 2.0 dan memungkinkan penciptaan dan pertukaran user-generated content. Web 2.0 menjadi platform dasar media sosial. Media sosial ada dalam berbagai bentuk yang berbeda, termasuk sosial network, forum internet, weblogs, sosial blogs, micro blogging, wikis, podcasts, gambar, video, ratting, dan bookmark sosial. ${ }^{4}$

Media Sosial menurut Dailey adalah konten online yang dibuat menggunakan teknologi penerbitan yang sangat mudah diakses dan terukur. Paling penting dari teknologi ini adalah terjadinya pergeseran cara mengetahui orang, membaca dan berbagi berita, serta mencari informasi dan konten. Ada ratusan saluran sosial media yang beroperasi di seluruh dunia saat ini, dengan tiga besar facebook, linkedln, dan twitter. ${ }^{5}$

Media sosial adalah sebuah media online, dengan para penggunanya bisa dengan mudah berpartisipasi, berbagi, dan menciptakan isi meliputi blog, jejaring sosial, wiki, forum dan dunia virtual. Blog, jejaring sosial dan wiki merupakan bentuk media sosial

3 Hadi Purnama, Media Sosial di Era Pemasaran 3.0 Corporate And Marketing Communication, (Jakarta: 2010). hlm. 112

${ }^{4}$ Lesmana, Gusti Ngurah Aditya, Analisis Pengaruh Media Sosial Twitter Terhadap Pembentukan Brand Attachment, Tesis, (Jakarta. Universitas Indonesia, 2012), hlm. 10

5 Dailey, Patrick R, Social Media: Finding Its Way into Your Business Strategy and Culture. Burlington, Linkage, 2012 
yang paling umum digunakan oleh masyarakat di seluruh dunia. Media sosial teknologi mengambil berbagai bentuk termasuk majalah, forum internet, weblog, blog sosial, microblogging, wiki, podcast, foto atau gambar, video, peringkat, dan bookmark sosial. Dengan menerapkan satu set teori-teori dalam bidang media penelitian (kehadiran sosial, media kekayaan) dan proses sosial (self-presentasi, self-disclosure) Kaplan dan Haenlein menciptakan skema klasifikasi untuk berbagai jenis media sosial dalam artikel Horizons Bisnis mereka diterbitkan dalam 2010. Menurut Kaplan dan Haenlein ada enam jenis media sosial: proyek kolaborasi (misalnya, Wikipedia), blog dan microblogs (misalnya, Twitter), komunitas konten (misalnya YouTube), situs jaringan sosial (misalnya Facebook), game virtual dunia (misalnya, World of Warcraft), dan dunia sosial virtual (Second Life misalnya). ${ }^{6}$

Karjaluoto mengungkapkan bahwa istilah media sosial menggambarkan sebuah media sehingga para pengguna dapat dengan mudah berpartisipasi dan memberi kontribusi di dalam media tersebut. Karakteristik umum yang dimiliki setiap media sosial yaitu adanya keterbukaan dialog antar para pengguna. Sosial media dapat dirubah oleh waktu dan diatur ulang oleh penciptanya, atau dalam beberapa situs tertentu, dapat diubah oleh suatu komunitas. Selain itu sosial media juga menyediakan dan membentuk cara baru dalam berkomunikasi. Seperti diketahui, sebelum muncul dan populernya media sosial, kebanyakan orang berkomunikasi dengan cara sms atau telpon lewat handphone. Namun sekarang dengan adanya media sosial, orang cenderung berkomunikasi lewat layanan obrolan (chat) atau berkirim pesan lewat layanan yang tersedia di media sosial. ${ }^{7}$

\section{b. Karakteristik Media Sosial}

Menurut Meredith G. Farkas media sosial, secara umum dalam pemanfaatannya memiliki 9 karateristik yang dirinci sebagai berikut ${ }^{8}$ :

${ }^{6}$ Kaplan, Andreas M.; Michael Haenlein, Users of the world, unite! The challenges and opportunities of Social Media, (Business Horizons: 2010), hlm. 59-68

7 Karjaluoto, A Primer in Social Media. Examining The Phenomenon, Its Relevance, Promomise, and Risks (paper), A SmashLAP White, 1 Maret 2008. hlm. 3

${ }^{8}$ Farkas, Meredith G. Social Software In Libraries: Building Collaboration, Communication, and Community Online, New Jersey: Information Today. Inc, 2007. 
1) Kemudahan dalam membuat dan membagikan konten

Dengan menggunakan sosial media siapa pun dapat membuat konten online, termasuk foto, teks, audio, dan video. Kemudian dengan mudah dan cepat dapat menyebarkanya.

2) Kolaborasi online

kolaborasi dalam menulis konten sangat mudah untuk dilakukan oleh siapapun, di manapun dan kapanpun. Dengan wiki, siapa pun dapat menambahkan atau merubah isi artikel. Wiki juga dapat digunakan bersama-sama untuk mengembangkan panduan atau basis pengetahuan.

3) Percakapan dapat dibagikan secara real- time

Media sosial memungkinkan percakapan terjadi dalam berbagai bentuk. Dengan media sosial sebuah komunikasi terjadi dan seketika itu juga dapat dibagikan secarareal-time.

4) Masyarakat berkembang dari bawah ke atas

Media sosial membantu kita membangun berbagai jenis masyarakat. Saat ini banyak masyarakat online yang tidak lagi memerlukan forum, papan buletin, atau email. Percakapan bisa berlangsung di wiki, di bagian komentar blog, atau melalui berbagai software media sosial. Komunitas seperti ini terbentuk karena adanya beberapa orang yang menggunakan media sosial yang sama atau mempunyai fokus kegiatan atau hobi serupa.

5) Memanfaatkan kebijaksanaan dari banyak orang

Tidak hanya dapat berkomunikasi, berkolaborasi, dan membangun komunitas online, tapi kita bisa belajar banyak dari pengetahuan dan perilaku orang karena lebih banyak orang berpartisipasi dalam media sosial.

6) Transparan

Dengan media sosial sebuah perpustakaan dapat terhubung dengan pemustakanya secara pribadi dan dapat diketahui oleh semua orang. Tidak ada hal yang ditutup-tutupi dengan menggunakan media sosial. 
7) Personalisasi

Dengan teknologi RSS telah memungkinkan seseorang untuk berlangganan artikel secara tertentu sesuai dengan topik yang dia inginkan, hal ini bisa.

8) Portabilitas

Semua media sosial selalu terhubung dengan internet sehingga memungkinkan setiap orang untuk mengaksesnya secara 24 jam dimanapun dan kapanpun itu, dengan syarat pengguna terhubung dengan jaringan internet.

9) Mengatasi Hambatan Jarak dan Waktu

Media sosial mempunyai manfaat yang sangat baik untuk mengatasi hambatan jarakdan waktu, sekaligus memberikan kesempatan orang untuk berkomunikasi dan bekerja sama dimanapun mereka berada.

Sembilan karateristik media sosial ini telah memainkan peran penting sehingga telah mengubah pandangan seseorang untuk bisa berkomunikasi. Komunikasi saat ini dapat terjadi tanpa tatap muka, dan komunikasi bahkan dapat diketahui dan oleh banyak orang dalam satu waktu

Sedangkan menurut Hadi Purnama sosial media mempunyai beberapa karakteristik khusus diantaranya:

1) Jangkauan (reach): daya jangkauan social media dari skala kecil hinga khalayak global.

2) Aksesibilitas (accessibility): social media lebih mudah diakses oleh publik dengan biaya yang terjangkau.

3) Penggunaan (usability): social media relatif mudah digunakan karena tidak memerlukan keterampilan dan pelatihan khusus.

4) Aktualitas (immediacy): social media dapat memancing respon khalayak lebih cepat.

5) Tetap (permanence): social media dapat menggantikan komentar secara instan atau mudah melakukan proses pengeditan. ${ }^{9}$

9 Hadi Purnama, Media Sosial di Era Pemasaran 3.0 Corporate And Marketing Communication, (Jakarta: 2010). hlm. 114 


\section{c. Macam-macam Media Sosial}

Berdasarkan Karjaluoto media sosial ada 6 macam yaitu: ${ }^{10}$

1) Blog (blogs or web blogs), yaitu sebuah website yang dapat digunakan untuk memasang tulisan, baik oleh satu orang atau kelompok, dan juga menyediakan ruang sehingga pembaca tulisan dapat memberi komentar. Banyak macam-macam blog di dunia, dan blog menjadi popular karena menyediakan perspektif yang utuh dan asli mengenai topik-topik tertentu.

2) Forum (Forums), yaitu sebuah situs dimana beberapa pengguna (users) dapat menyusun topik dan mengomentari topik yang dibuat. Semua orang yang mengunjungi situs tersebut dapat memberikan komentar. Selain itu, biasanya forum ini dijadikan rujukan bagi mereka yang tertarik pada suatu topik. Contoh dari forum yang cukup popular adalah kaskus. Di dalam kaskus terdapat berbagai topik yang diciptakan oleh para pengguna situs atau diusulkan oleh para pengunjung situs tersebut.

3) Komunitas Konten (content communities), yaitu situs yang memungkinkan pengguna (users) untuk memasang atau menyebarkan konten. Konten yang dipasang dan disebarkan biasanya berupa video atau foto untuk bercerita dan berbagi. Beberapa situs ini menyediakan layanan untuk voting, sehingga pengunjung dapat ikut menentukan relevansi konten yang akan dipasang dan disebarkan.

4) Dunia virtual (virtual worlds), merupakan sebuah situs yang menyediakan dunia virtual bagi para pengunjungnya. Yaitu dunia yang seolah-olah nyata, dikarenakan pengunjung bisa saling berinteraksi dengan pengunjung lainnya, namun pada dasarnya dunia tersebut hanya ada di dalam internet. Salah satu contoh yang cukup popular dari dunia virtual adalah situs game on-line. Pengunjung dapat berinteraksi dan berjuang bersama dengan pengunjung lain atau dapat juga bersaing dengan pengunjung lain.

${ }^{10}$ Karjaluoto, A Primer in Social Media. Examining The Phenomenon, Its Relevance, Promomise, and Risks (paper), A SmashLAP White, 1 Maret 2008. hlm. 4 
5) Wikis, yaitu situs penghasil data-data atau dokumen-dokumen. Dalam situs ini, pengunjung yang telah diterima sebagai pengguna (users) resmi dapat mengganti atau menambah konten yang ada dalam situs dengan sumber yang lebih baik. Wikipedia merupakan salah satu contoh dari situs wikis.

6) Jejaring Sosial (social networks), yaitu komunitas virtual yang memungkinkan pengguna (users) untuk berkoneksi dengan pengguna (users) yang lainnya. Beberapa situs jejaring sosial dibuat untuk memperluas jaringan kelompok (contohnya Facebook), sementara yang lainnya dibuat berdasarkan wilayah tertentu saja (contohnya Linkedln).

\section{d. Fungsi dan Kegunaan Media Sosial untuk Perpustakaan}

1) Fungsi dan kegunaan media sosial untuk perpustakaan

a) Sebagai tempat berdiskusi, berinteraksi dan bersosialisasi tanpa harus bertemu secara fisik karena dapat dilakukan melalui forum-forum diskusi online maupun jejaring sosial yang ada.

b) Sebagai media promosi dalam kemajuan Perpustakaan itu sendiri.

c) Dapat mengikuti informasi ter update yang di update oleh pihak perpustakaan.

d) Mencari buku di perpustakaan tanpa harus menggunakan kartu katalog manual karena sudah ada katalog online yang disediakan oleh jejaring social untuk menelusurinya.

e) Meminjam buku di perpustakaan cukup dengan scan barcode maupun dibaca dengan alat berbasis Radio Frecuency Identifying (RFID) tanpa harus datang ke pustakawan untuk mencatat peminjaman secara manual.

f) Untuk memnuhi kebutuhan masyarakat, khususnya para pengguna media social yang ingin mengupdate tentang perpustakaan di daerahnya tetapi terhalang oleh jarak dan waktu. 
g) Sebagai media penunjang pembelajaran khususnya para siswa dan mahasiswa yang banyak menggunakan jejaring social, mereka dapat mendownload file dari jejaring social itu yang telah di upload oleh pihak perpustakaan. ${ }^{11}$

2) Tujuan Media Sosial untuk Perpustakaan

Media Sosial yang terkenal saat ini adalah Facebook dan Twitter. Perpustakaan saat ini setidaknya memiliki satu akun facebook dan satu akun Twitter. Pembuatan akun facebook dan twitter di perpustakaan, tujuan utamanya adalah membangun interaksi antara pustakawan dan pemustaka dalam menginformasikan berbagai aktivitas yang berkaitan dengan informasi peminjaman, perpanjangan peminjaman, pemesanan buku, kritik saran dan lain-lain. Selain itu, facebook dan twitter suatu perpustakaan dapat dijadikan sebagai media promosi dan membantu dalam pengembangan minat baca masyarakat. Sebagai media promosi misalnya, masyarakat yang berada jauh dari lingkungan perpustakaan akhirnya dapat mengetahui keberadaan perpustakaan tersebut dan sedikit mengetahui profilnya, karena dapata dilihat melalui facebook dan twitter. Sedangkan, dalam pengembangan minat baca, perpustakaan dapat mengupload cover buku terbaru dengan topik yang menarik, sehingga masyarakat akan penasaran dan tertarik untuk berkunjung di perpustakaan. Dalam hal ini, pustakawan memiliki peranan penting agar dalam pemanfaatan teknologi dilakukan secara maksimal. ${ }^{12}$

\section{e. Perpustakaan Daerah di Kota Literasi Kabupaten Sragen}

1) Sejarah Singkat Perpustakaan

Kantor Perpustakaan Daerah Kabupaten Sragen berdiri pada tahun 1980. Pada waktu itu, pengelolaan perpustakaan masih dilakukan oleh Bagian Hukum dan Ortala Setwilda Tk.

11 Windasari Kusumaputri, Penggunaan Media Sosial di Perpustakaan, 2015, http://www.winadkusuma.note.fisip.uns.ac.id/2015/12/07/penggunaanmedi-sosial--perpustakaan-2, diakses pada hari Jumat, 20 Januari 2017 pukul 13.00 WIB

12 Ibid. 
II Sragen. Setelah dikeluarkannya Peraturan Daerah No 11 Tahun 1990, pengelolaan perpustakaan hanya dilakukan oleh Bagian Ortala saja. Kemudian pada tahun 1992, pengelolaan perpustakaan diganti oleh Bagian Organisasi Setwilda Tk II, dan baru pada tahun 1996, berdasarkan Peraturan Daerah No 17, perpustakaan ditetapkan sebagai Unit Pelaksana Teknis Daerah Perpustakaan Umum Kabupaten Dati II Sragen, kemudian berdasarkan Perda No 3 Tahun 2001, perpustakaan ditetapkan sebagai Kantor Perpustakaan Kabupaten Sragen. Setelah dua tahun ditetapkan menjadi Perpustakaan Daerah, pada tahun 2004, nama perpustakaan diubah lagi, hal ini didasarkan pada Peraturan Bupati Sragen Nomor 7 yang menjadi UPTD perpustakaan Dinas P \& K Kabupaten Sragen. Dengan adanya Peraturan Daerah Kabupaten Sragen Nomor 15 tahun 2008, dimana nama perpustakaan ditetapkan menjadi Kantor Perpustakaan Daerah Sragen sebagai kantor yang mempunyai tugas pokok membantu pemerintah daerah dalam mengembangkan perpustakaan-perpustakaan di lingkungan Kabupaten Sragen. ${ }^{13}$

Perpustakaan Daerah Kabupaten Sragen sekarang dibagi menjadi 3 bagian dalam pelayanan pemustaka. Gedung pertama ialah perpustakaan utama yang beralamat di Jalan Pemuda No. 1 Sragen, gedung kedua yang berorientasi khusus layanan anak beralamat di Jalan Raya Sukowati barat No. 15 D serta gedung ketiga yeng terletak di jalan Mawar No. 5 A yang difungsikan untuk Taman Bacaan (Manca). Penelitian ini difokuskan di perpustakaan utama yang beralamat di Jalan Pemuda No. 1 Sragen. ${ }^{14}$

2) Visi dan Misi Perpustakaan

Kantor Perpustakaan Daerah Kabupaten Sragen mempunyai visi dan misi sebagai berikut: ${ }^{15}$

\footnotetext{
${ }^{13}$ Dokumentasi Profil Perpustakaan Daerah Kabupaten Sragen

${ }^{14}$ Dokumentasi Profil Perpustakaan Daerah Kabupaten Sragen

15 Dokumentasi Profil Perpustakaan Daerah Kabupaten Sragen
} 
a) Misi

Terwujudnya perpustakaan berbasis teknologi informasi sebagai pusat literasi dan informasi masyarakat Sragen yang cerdas dan sejahtera.

b) Misi

Adapun misi dari keberadaan Kantor Perpustakaan daerah Sragen ialah:

i. Menyediakan koleksi bahan pustaka yang bermutu dan sesuai dengan kebutuhan masyarakat Sragen.

ii. Melayanai kebutuhan masyarakat Sragen terhadap ilmu pengetahuan dan informasi.

iii. Menumbuhkan, merangsang, mengembangkan seluruh perpustakaan dan taman bacaan yang ada di Kabupaten Sragen.

iv. Melestarikan karya ilmu pengetahuan, teknologi, budaya dan seni masyarakat Sragen.

3) Tugas Pokok dan Fungsi Perpustakaan

Adapun tugas dan fungsi dari Kantor Perpustakaan Daerah Kabupaten Sragen antara lain: ${ }^{16}$

a) Tugas

Kantor Perpustakaan Daerah mempunyai tugas melaksanakan sebagian tugas Pemerintahan Daerah di bidang perpustakaan.

b) Fungsi

i. Perumusan kebijaksanaan teknis di bidang pengembangan, pembinaan, dan pendayagunaan perpustakaan.

ii. Penyusunan dan pelaksanaan rencana strategis dan rencana kerja tahunan di bidang pengambangan, pembinaan, dan pendayagunaan perpustakaan.

iii. Penyelenggaraan pendidikan dan latihan, dan pembinaan sumber daya manusia di bidang perpustakaan.

${ }^{16}$ Dokumentasi Profil Perpustakaan Daerah Kabupaten Sragen 
iv. Pelaksanaan kerjasama di bidang perpustakaan dan informasi dengan badan ataupun lembaga lain, baik di dalam maupun di luar daerah.

v. Pelaksanaan pembinaan semua jenis perpustakaan, baik perpustakaan di instansi atau lembaga pemerintah maupun swasta yang ada di daerah.

vi. Pelaksanaan pengumpulan, penyimpanan, pengolahan, dan pelayanan bahan pustaka dari dalam dan luar daerah serta perawatan dan pelestarian bahan pustaka.

vii. Pengolaan karya cetak dan karya rekam sesuai dengan ketentuan peraturan perundang-undangan yang berlaku.

viii. Pelaksanaan penyusunan naskah bibliografi , catalog daerah, induk daerah, bahan rujukan berupa indeks, bibliografi subyek, abstrak, dan penyusunan perangkat lunak lainnya.

ix. Pelaksanaan jasa koleksi seperti bahan rujukan, naskah, multimedia, dan jaringan automasi perpustakaan.

x. Pelaksanaan pembentukan jaringan informasi perpustakaan di lingkungan Pemerintah Daerah.

4) Layanan Perpustakaan

Perpustakaan Daerah Kabupaten Sragen memiliki sistem layanan terbuka dengan jadual layanan senin-kamis dan sabtu buka pukul 08.00 - 20.00 WIB, hari jumat buka pukul 08.00 17.00 WIB, serta hari minggu buka pukul 09.00 - 13.00 WIB. Jenis layanan yang ada di Perpustakaan Dearah Sragen antara lain: layanan sirkulasi, layanan referensi, layanan terbitan berkala, layanan internet gratis, layanan online, layanan perpustakaan keliling dan layanan khusus anak. ${ }^{17}$

a) Layanan Sirkulasi

Layanan sirkulasi terletak di ruang utama perpustakaan, berdampingan dengan ruang-ruang petugas perpustakaan, jam buka layanan ini sama seperti jam buka

${ }^{17}$ Dokumentasi Profil Perpustakaan Daerah Kabupaten Sragen 
perpustakaan. Sistem yang digunakan dalam layanan ini ialah sistem layanan terbuka, dimana pemustaka dapat memilih sendiri bahan pustaka di jajaran koleksi kemudian koleksi tersebut dapat dibaca di tempat atau dipinjam dengan batas maksimal peminjaman 1 minggu.

Selain itu, layanan sirkulasi sekarang ini telah dilengkapi dengan fasilitas hotspot, dimana pemustaka dapat memanfaatkan fasilitas tersebut secara gratis, sehingga terkadang ada pemustaka yang hanya memanfaatkan layanan hotspot-nya saja, tidak meminjam atau membaca buku. Koleksi yang terdapat dalam layanan sirkulasi dikelompokkan berdasarkan aturan persepuluhan dewey yang meliputi karya umum, filsafat, agama, ilmu sosial, bahasa, ilmu murni, teknologi terapan, kesenian dan olahraga, kesusastraan, geografi dan sejarah serta kelompok buku fiksi.

b) Layanan Referensi

Layanan referensi terletak bersebelahan dengan layanan sirkulasi dan bersamaan dengan layanan internet. Sistem layanan yang digunakan yaitu sitem layanan terbuka. Namun, koleksi yang ada tidak boleh dipinjamkan, hanya boleh dibaca di tempat, apabila ada pemustaka yang ingin memfotocopi buku di layanan referensi ini, maka harus meninggalkan identitas kepada petugas layanan. Koleksi yang terdapat dalam layanan referensi antara lain: koleksi buku braile (Al-Quran Brailie), buku langka (rare old book), serta buku daerah.

c) Layanan Terbitan Berkala

Layanan ini terletak bersebelahan dengan ruang referensi. Jam buka layanan sama seperti jam buka perpustakaan. Sistem layanan yang digunakan yaitu sistem layanan terbuka. Namun, koleksi yang ada tidak dipinjamkan, hanya boleh dibaca di tempat. Apabila ada pemustaka yang ingin mengkopi koleksi di layanan terbitan 
berkala ini, maka pemustaka harus meninggalkan kartu identitas kepada petugas layanan tersebut. Koleksi yang terdapat di layanan ini antara lain: Surat kabar harian yang berupa Surat Kabar Kompas, Suara Merdeka, Solopos dan Wawasan. Tabloid yang berupa Tabloid Bola, Nova, Komputer, Teen, Rumah dan Hikmah. Majalah yang berupa Majalah Trubus, Bobo, Hidayah, Sabili, Penjebar Semangat dan Genta.

5) Layanan Internet Gratis

Layanan internet gratis merupakan layanan internet yang dapat dimanfaatkan pemustaka yang ingin memperoleh informasi melalui internet. Layanan internet gratis terletak bersamaan dengan layanan referensi. Layanan internet gratis memiliki 4 unit komputer dengan peralatan lain seperti burning dan scanner. Namun, dilihat dari kondisi sekarang peralatan komputer yang bisa digunakan untuk pemustaka hanya 2 unit.

6) Layanan Online

Layanan perpustakaan ini dapat diakses di dunia maya melalui blog www.perpustakaansregen.blogspot.com. Di blog tersebut, pengunjung dapat mengakses resensi buku, opini dan membaca buku digital secara langsung.

7) Layanan Perpustakaan Keliling

Layanan perpustakaan keliling memiliki 4 unit mobil dan 1 unit sepeda motor. Perpustakaan keliling melayani masyarakat di pelosok Kabupaten Sragen. Di setiap kecamatan terdapat 4 sekolah yang dilayani, layanan di taman wisata dan pendidikan Dayu Alam Asri dilakukan setiap hari sabtu dan minggu, seta layanan perpustakaan keliling di alun-alun dilakukan setiap hari senin, rabu dan sabtu sore. Kendala dalam layanan ini adalah minimnya jumlah buku dan anggaran bahan bakar yang terbatas.

8) Layanan Khusus Anak

Layanan khusus anak buka setiap hari mulai pukul 08.00 - 13.00 WIB. Layanan ini diperuntukkan untuk anak usia 
dini sampai usia sekolah dasar. Layanan yang diberikan, antara lain: layanan pemutaran film edukatif, layanan story telling/ mendongeng, layanan seni musik, serta layanan APE (Alat Permainan Edukatif). Layanan khusus anak terletak di Gedung Perpustakaan Unit II Jl. Raya Sukowati 15 D. Kendala yang ada di layanan khusus anak saat ini ialah belum memilikinya orgen tunggal sendiri, selama layanan ini digunakan pihak perpustakaan menyewa orgen dari tempat lain. ${ }^{18}$

\section{Penerapan Pemanfaatan Media Sosial Pada Perpustakaan Daerah Kabupaten Sragen}

Perkembangan teknologi informasi membantu mempermudah pekerjaan dan untuk menunjang kepentingan manusia. Koneksi internet banyak memberi kemudahan dan kecepatan akses informasi yang beragam bagi siapapun, mulai dari anak-anak hingga orang dewasa, lembaga atau institusi, tidak terkecuali perpustakaan. Perpustakaan sebagai suatu lembaga penyedia informasi memiliki peranan penting untuk menyediakan dan melayani pemustaka dalam memperoleh informasi secara cepat, mudah, efektif dan efisien. Pelayanan yang ramah dan hangat tentu akan disukai para pemustaka. Hal ini akan berdampak pada intensitas pengunjung perpustakaan yang meningkat, karena akan menimbulkan kesan yang positif terhadap pustakawan dan stafnya yang memberikan pelayanan secara excellent. Namun, semakin berkembangnya teknologi informasi dan telekomunikasi saat ini dapat membawa perubahan pada pelayanan suatu perpustakaan. Kemudahan pelayanan kepada pemustaka, dalam hal ini didapatkan dengan memanfaatkan media sosial berbasis web atau jejaring sosial seperti Facebook dan Twitter. Facebook dan Twitter merupakan sebagian contoh dari jejaring sosial yang ada saat ini dan semakin banyak bermunculan, yang pemanfaatannya dapat diterapkan di perpustakaan.

Teknologi dapat memberi dampak baik maupun dampak buruk, bergantung kepada manusia yang menggunakannya. Selama teknologi itu digunakan untuk hal-hal yang postif, tentu akan

${ }^{18}$ Dokumentasi Profil Perpustakaan Daerah Kabupaten Sragen 
memberi manfaat bagi manusia, begitupun sebaliknya. Demikian pula perkembangan teknologi informasi di perpustakaan, dengan memanfaatkan media sosial berbasis web atau jejaring sosial, bukan untuk melarang pemustaka berkunjung ke perpustakaan, melainkan bermaksud memberi kemudahan akses kepada pemustaka dalam mendapat informasi mengenai keterlambatan peminjaman koleksi, perpanjangan peminjaman koleksi, jumlah denda, pemesanan buku, kritik saran dan lain-lain. Teknologi, khususnya teknologi informasi di bidang perpustakaan akan terus mengalami perubahan, untuk itu pentingnya peranan pustakawan dalam memanfaatkan dan menggunakan teknologi informasi secara baik dan bijak untuk kepuasan pengunjung atau pengguna perpustakaan.

Berdasarkan hasil wawancara dengan Ibu Mey Sumarlina selaku staf bagian layanan perpustakaan dan informasi, menjelaskan bahwa pemanfaatan media sosial pada Perpustakaan Daerah Kabupaten Sragen yang telah diterapkan adalah sebagai berikut: ${ }^{19}$

\section{a. Pemanfaatan Blog Sebagai Layanan Online}

Salah satu media sosial yang digunakan di Perpustakaan Daerah Kabupaten Sragen adalah dengan menggunakan web blog. Layanan perpustakaan ini dapat diakses di dunia maya melalui blog www.perpustakaansregen.blogspot.com. Di blog tersebut, pengunjung dapat mengakses resensi buku, opini dan membaca buku digital secara langsung. Berikut ini adalah gambar pemanfaatan media tersebut

19 Sumber: Hasil wawancara dengan Ibu Mey Sumarlina selaku staf bagian layanan perpustakaan dan informasi, pada Hari Senin, 23 Januari 2017 


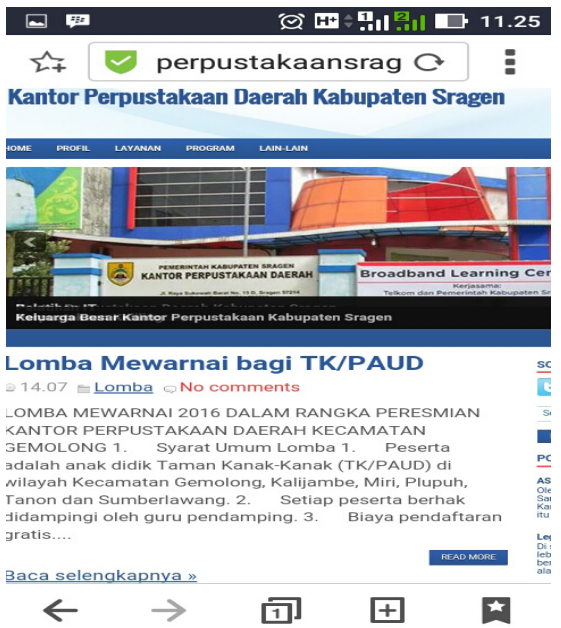

Gambar 1. Halaman Depan Blog Perpustakaan Daerah Kabupaten Sragen

Menurut Fichter, Blog, kependekan dari Weblog, adalah situs Web yang memuat entri-entri singkat, ditampilkan dalam urutan kronologis terbalik. Blog ini cukup bervariasi, dari catatan harian seseorang sampai pada situs berita yang memantau perkembangan dalam topik apapun dari berita di luar Mongolia sampai ke masalah hak cipta. ${ }^{20}$

Fitcher menuliskan yang bisa dilakukan perpustakaan dengan blog sebagai berikut:

1. Mempromosikan kegiatan perpustakaan

2. Mendukung pengguna perpustakaan yang setia memanfaatkan layanan perpustakaan

3. Menciptakan kedekatan dengan komunitas yang dilayani

4. Mendukung komunitas yang dilayani

5. Menciptakan ikatan-ikatan baru ${ }^{21}$

Dengan keterbatasan SDM, waktu, dan dana yang merupakan keluhan yang sering kita dengarkan dari para pustakawan, blog merupakan pilihan yang sangat sesuai untuk

20 Anita Nuasantari dan Henny Linggawati, Pemanfaatan Blog Dalam Memasarkan Perpustakaan: Mengapa Tidak?, Majalah Visi Pustaka Edisi Vol. 9 No. 2 Agustus 2007

${ }^{21}$ Ibid 
mempromosikan kegiatan perpustakaan. Tentunya dalam hal ini dituntut kekreatifan pustakawan untuk memanfaatkan fasilitas yang murah meriah ini. Contoh kegiatan pemasaran layanan perpustakaan yang dapat dilakukan dengan fasilitas blog ini adalah promosi koleksi baru yang dimiliki perpustakaan. Fitcher menyarankan untuk mengelompokkan koleksi baru kedalam topik-topik yang menarik seperti: horror, misteri, roman, fiksi dan lain sebagainya. Sangat menarik apabila diadakan review buku baru dan didiskusikan dengan pengguna dan libatkan pengguna agar bisa merekomendasikan ke pengguna lain. Dapat juga dilakukan promosi program minat baca bagi komunitas yang dilayani. ${ }^{22}$

Fitcher memberikan tip-tip berguna yang dapat menarik pengguna untuk mengunjungi blog perpustakaan tersebut, misalnya kutipan-kutipan dari karya-karya sastra terkenal yang selalu di update setiap hari, mengadakan kuis setiap hari Jumat, berbagi hal-hal yang pengalaman-pengalaman yang menarik tentang kampus seminggu sekali dan lain sebagainya. ${ }^{23}$

Dari uraian di atas jelaslah, bahwa blog adalah salah satu alternatif media yang memberikan peluang bagi perpustakaan untuk memasarkan produk dan layanannya. Dengan keterbatasan dana dan sumber daya manusia yang selalu menjadi keluhan perpustakaan, fasilitas blog adalah salah satu solusi untuk melakukan pemasaran layanan perpustakaan yang efektif. Pembuatan Blog sangat mudah karena tidak memerlukan seorang ahli komputer untuk menanganinya dan tidak memakan biaya untuk penempatannya, karena adanya penyedia layanan blog yang gratis. Tetapi perpustakaan tetap dituntut untuk berperan aktif untuk menjaga kekinian (kemutakhiran) dari isi blog tersebut. Hal ini merupakan kunci utama dalam mengelola blog untuk tetap bertahan.

\section{b. Pemanfaatan Jejaring Sosial}

Pemanfaatan media sosial yang digunakan selain web blog adalah dengan menggunakan media jejaring sosial seperti facebook.
${ }^{22}$ Ibid
${ }^{23}$ Ibid 
Dalam pemanfaatannya, Perpustakaan Daerah Sragen menjadikan facebook sebagai media untuk mempromosikan diri. Selain itu juga memberikan informasi kepada pembaca tentang koleksi buku, cara peminjaman dan pengembalian buku, buku online, kegiatankegiatan perpustakaan dan lain sebagainya. ${ }^{24}$ Berikut ini adalah contoh pemanfaatan media sosial facebook pada perpustakaan daerah sragen:

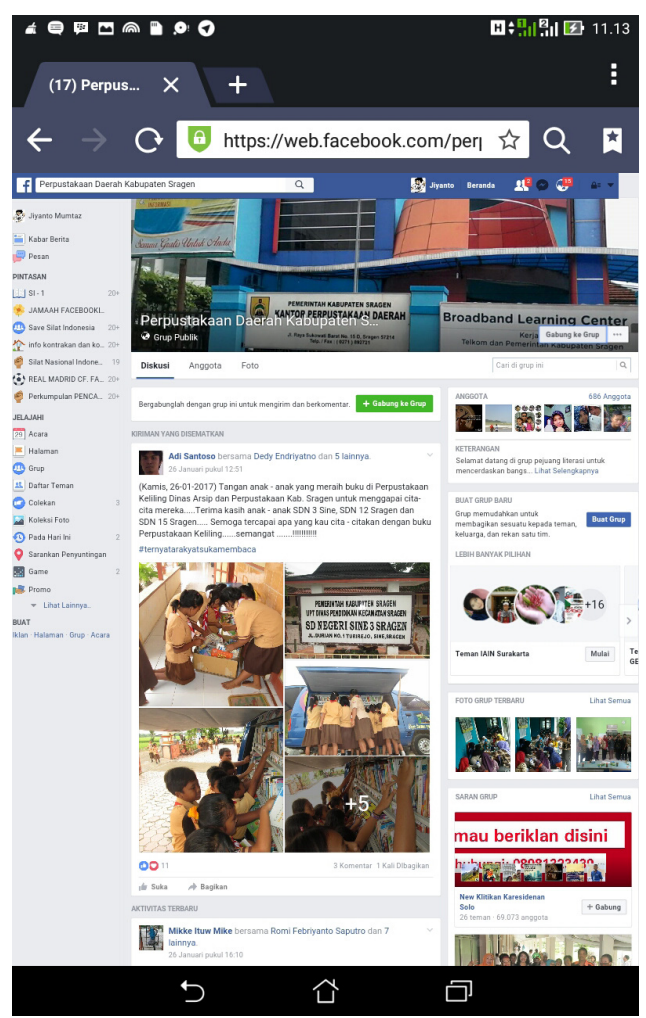

Gambar 2. Halaman depan akun Facebook Perpustakaan Daerah Kabupaten Sragen

Facebook merupakan jejaring sosial yang sangat populer beberapa tahun belakangan ini. Media ini sangat diminati semua kalangan dan hampir setiap orang diseluruh belahan dunia termasuk Indonesia seperti terjangkit virus Facebook. Kemudahan akses internet yang disediakan oleh berbagai provider seluler membuat

${ }^{24}$ Sumber: Hasil wawancara dengan Ibu Mey Sumarlina selaku staf bagian layanan perpustakaan dan informasi, pada Hari Kamis, 26 Januari 2017 
Facebook menjadi lebih populer dibandingkan situs jejaring sosial lainnya. Indonesia memang bukan lagi negara dengan pengguna facebook terbesar kedua di dunia setelah Amerika Serikat (digantikan oleh India), namun jumlah penggunanya secara keseluruhan tetap besar karena dalam kurun waktu 6 bulan terakhir jumlah pengguna facebook di Indonesia bertambah sekitar 3.889.180, artinya kini jumlah pengguna facebook di Indonesia mewakili 17,72 \% jumlah penduduk atau sekitar 45 juta orang. ${ }^{25}$

Keberadaan facebook banyak membantu perpustakaan sebagai information dan knowledge center dalam menyebarkan informasi secara cepat dan tepat. Facebook sebagai salah satu situs di internet dapat dijadikan media komunikasi massa yang memiliki fungsi sama dengan media massa lainnya yaitu menginformasikan (to inform), mendidik (to educated), menghibur (to entertaint) dan mempengaruhi (to influence) orang lain, dalam hal ini pemustaka perpustakaan.

\section{c. Pemanfaatan Youtube}

Media sosial yang ketiga yang digunakan adalah dengan youtube. Media ini berbeda dengan media sosial yang lainnya. Youtube digunakan untuk memberikan informasi-informasi terkait kegiatankegiatan yang dilakukan oleh Perpustakaan Daerah Kabupaten Sragen yang telah didokumentasikan dalam bentuk video. ${ }^{26}$ Berikut ini adalah contoh pemanfaatan media youtube untuk perpustakaan:

${ }^{25}$ Tri Wahono, KOMPAS.com, Rabu 1 Februari 2012

26 Sumber: Hasil Wawancara dengan Bapak Romy Febriyanto , pada hari Senin, 23 Januari 2017 


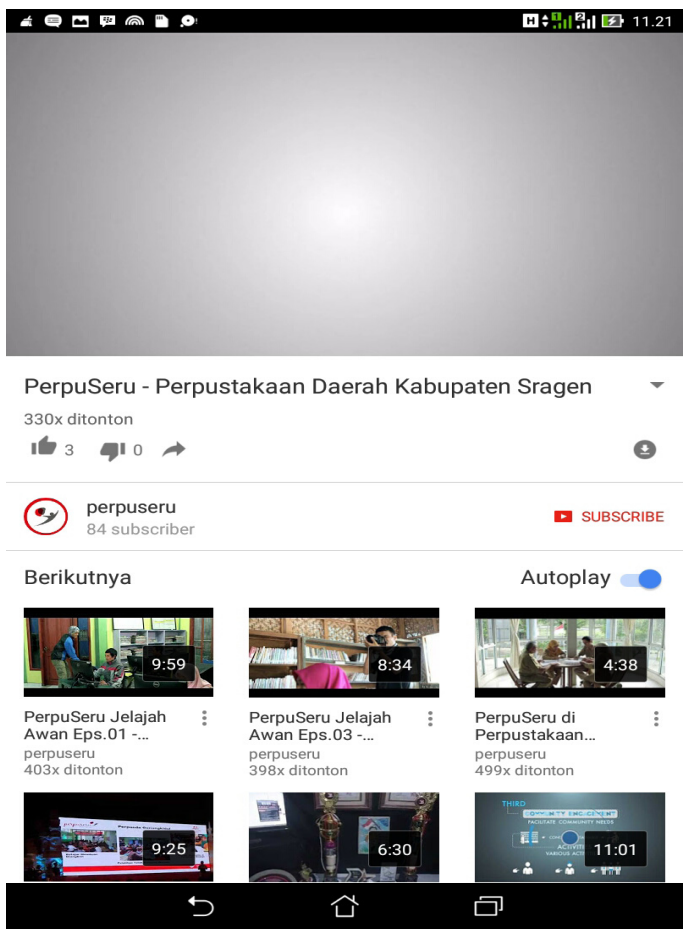

Gambar 3. Pemanfaatan media Youtube pada Perpustakaan Daerah Kab. Sragen

Penggunaan media sosial youtube di perpustakaan juga tidak kalah dengan media sosial yang lain. Akun youtube untuk membagikan hasil dokumentasi sebuah kegiatan sekaligus promosi sedangkan perpustakaan memanfaatkan youtube untuk berbagi informasi layanan perpustakaan.

\section{Simpulan}

Dari uraian di atas dapat disimpulkan bahwa pemanfaatan media sosial di Perpustakaan Daerah Kabupaten Sragen adalah sebagai sarana promosi perpustakaan. Contohnya memperkenalkan fasilitas, koleksi dan jenis layanan. Selain itu juga memberikan tempat untuk berbagi berita terbaru tentang perpustakaan. Pencanangan kota Sragen sebagai Kabupaten Literasi menjadikan perpustakaan sebagai pusat kegiatan dalam program pemerintah tersebut. Dalam mendukung program pemerintah tersebut, Perpustakaan Umum Daerah Sragen 
membutuhkan berbagai sarana penunjang dalam mempromosikan diri sebagai pusatnya literasi. Salah satu sarana penunjang yang efektif adalah dengan menggunakan sosial media. Adapun media sosial yang digunakan antara lain web blog, jejaring sosial facebook dan youtube.

Dengan memanfaatkan media sosial bukan berarti kita menjadikan para pemustaka menjadi malas ke perpustakaan karena informasi yang diperlukan dapat didapatkan tanpa harus pergi ke perpustakaan, namun intinya para pustakawan bermaksud untuk memberikan kemudahan kepada para pemustaka untuk mendapatkan informasi demi pemenuhan kebutuhan informasi melalui pemanfaatan akun media sosial yang dimiliki oleh perpustakaan. 


\section{DAFTAR PUSTAKA}

Dailey, Patrick R, Social Media: Finding Its Way into Your Business

Strategy and Culture. Burlington, Linkage, 2012

Dokumentasi Profil Perpustakaan Daerah Kabupaten Sragen, 2017

Farkas, Meredith G. Social Software In Libraries: Building Collaboration, Communication, and Community Online, New Jersey: Information Today. Inc, 2007

Hasil Wawancara dengan Ibu Dewi Nurlaila Cahya Sari selaku Staf Bagian Pengadaan, Pengelolaan, Dan Pelestarian Bahan, pada hari Senin, 23 Januari 2017

Hasil wawancara dengan Ibu Mey Sumarlina selaku staf bagian layanan perpustakaan dan informasi, pada Hari Senin, 23 Januari 2017

Kaplan, Andreas M.; Michael Haenlein, Users of the world, unite! The challenges and opportunities of Social Media, Business Horizons: 2010

Karjaluoto, A Primer in Social Media. Examining The Phenomenon, Its Relevance, Promomise, and Risks (paper), A SmashLAP White, 1 Maret 2008

Karjaluoto, A Primer in Social Media. Examining The Phenomenon, Its Relevance, Promomise, and Risks (paper), A SmashLAP White, 1 Maret 2008

Kompas, Minat Baca Indonesia ada di urutan ke-60 Dunia, 2016, http://www.edukasi.kompas.com/read/2016/08/29/07175131/ minat.baca.indonesia.ada.di.urutan.ke-60.dunia, Diakses pada 31 Desember 2016 pada pukul 08.00 WIB

Kusumaputri, Windasari, Penggunaan Media Sosial di Perpustakaan, 2015 , http://www.winadkusuma.note.fisip.uns. ac.id/2015/12/07/penggunaan-medi-sosial--perpustakaan-2, diakses pada hari Jumat, 20 Januari 2017 pukul 13.00 WIB 
Lesmana, Gusti Ngurah Aditya, Analisis Pengaruh Media Sosial Twitter Terhadap Pembentukan Brand Attachment, Tesis, Jakarta. Universitas Indonesia, 2012

Nuasantari, Anita dan Henny Linggawati, Pemanfaatan Blog Dalam Memasarkan Perpustakaan: Mengapa Tidak?, Majalah Visi Pustaka Edisi Vol. 9 No. 2 Agustus 2007

Purnama, Hadi, Media Sosial di Era Pemasaran 3.0 Corporate And Marketing Communication, Jakarta: 2010

Tri Wahono, KOMPAS.com, Rabu 1 Februari 2012

USAID Prioritas, Sragen Deklarasikan Jadi Kabupaten Literasi, 2016, http://www.prioritaspendidikan.org/id/post/920/sragen/deklarasikan-jadi-kabupaten-literasi, diakses pada 31 Desember 2016 pada pukul 08.00 


\section{UCAPAN TERIMA KASIH}

Redaksi Jurnal LIBRARIA, Jurnal Perpustakaan Sekolah Tinggi Agama Islam Negeri Kudus menghaturkan penghargaan dan ucapan terima kasih kepada:

\section{MITRA BEBESTARI}

1. Dra. Labibah, M.LIS (Kapus. UIN Sunan Kalijaga, Yogyakarta)

2. Dra. Retno Sayekti, M.LIS (Kaprodi. Ilmu Perpustakaan UIN Sumatera Utara)

3. Dr. Sirojul Arifin, S.Ag, SS, M.E.I (Kapus. UIN Sunan Ampel Surabaya)

4. Muhammad Azwar, S.Pd.I, M.Hum (Dosen Ilmu Perpustakaan UIN Sarif Hidayatullah, Jakarta)

5. Wahibur Rokhman, SE, M.Si, Ph.D (Dosen Pascasarjana STAIN Kudus)

6. Dr. Adri Efferi, M.Ag (Direktur Pascasarjana STAIN Kudus)

7. Dr. H. Nur Mahmudah, MA (Dosen Pascasarjana STAIN Kudus)

Atas kesediaan dan ketulusannya menelaah, mengoreksi dan menilai naskah Jurnal LIBRARIA media pengkajian, pengembangan dan penganalisisan /pengkritisan karya ilmu kepustakawanan Volume 5, Nomor 1-2, Tahun 2017. 
